\title{
Interpretation of the Legislation Provisions Related To the Continuing Offences
}

\author{
Gan Chee Keong \\ Independent Researcher, Malaysia
}

\begin{abstract}
The purpose of this writing is to examine how these legislation provisions related to the continuing offences ("legislation provisions") are interpreted. The continuing offence is one, which is susceptible of continuous and is distinguishable from the one that is committed once and for all. It is one of those offences which arises out of a failure to comply with a rule which involves a penalty, the liability for which continues until the rule is complied with. The legislation provisions is not something new for such provisions can be found employed in statutes of many Commonwealth countries. Reading the legislation provisions in question, one may interpret that continuing offence forms part of the principal offence, therefore, a person can be charged again for the same principal offence together with an additional punishment if an offence had been continued ("first interpretation"). On the other hand, one may also interpret that continuing offence is a separate and distinct offence. Thus, a person can only be charged once for the same principal offence. If an offence had been continued, he/she will only be charged for the continuing offence ("second interpretation"). The problem arises with regard to the interpretation, as there is possibility of different interpretations for a common legislation provisions that may cause confusion. The method used in the present research is doctrinal legal research that focusing on case law and statutes. From the research conducted, the researcher finds that: (1) the penalty for a continuing offence can be imposed only after proof that the offence has continued; (2) the proper procedure is to prosecute the offender under a fresh charge for continuing offence; (3) In the absence of fresh charge for continuing offence, it will not be possible for the court to determine how long the default had gone. The researcher further finds that if a person can be charged again for the same principal offence based on the first interpretation, it will amount to double jeopardy, which is prohibit under Article 7(2) Federal Constitution 1957 (Malaysia). In conclusion, the second interpretation is more tenable. Hence, the researcher proposes that a practice direction or guideline should be laid down to assist the relevant authorities in the matter of interpretation of the legislation provisions.
\end{abstract}

Keywords: continuing offence; double jeopardy; interpretation; legislation provisions; principal offence 